\title{
Effects of exogenous fibrolytic enzymes on the ruminal fermentation of agro-industrial by-products
}

\author{
K. Abid ${ }^{1,2 \#}$, J. Jabri', Y. Beckers ${ }^{3}$, H. Yaich', A. Malek, J. Rekhis ${ }^{1} \&$ M. Kamoun ${ }^{1}$ \\ ${ }^{1}$ Food and Animal Nutrition Service, National School of Veterinary Medicine Sidi Thabet, University of Manouba, Tunisia \\ ${ }^{2}$ Institut Supérieur Agronomique de Chott-Mariem, University of Sousse, Tunisia \\ ${ }^{3}$ Laboratories Precision Livestock and Nutrition, Gembloux Agro-Bio Tech, University of Liege, Belgium
}

(Received 20 September 2018; Accepted 22 April 2019; First published online 5 July 2019)

\author{
Copyright resides with the authors in terms of the Creative Commons Attribution 4.0 South African License. \\ See: http://creativecommons.org/licenses/by/4.0/za \\ Condition of use: The user may copy, distribute, transmit and adapt the work, but must recognize the authors and \\ the South African Journal of Animal Science.
}

\begin{abstract}
This research was performed to evaluate the effects of increasing doses of exogenous fibrolytic enzymes (EFE), namely at 0 (control), 1 (low), 2 (medium) and 4 (high) $\mu \mathrm{L} / \mathrm{g}$ dry matter (DM), on the ruminal fermentation of low-quality agro-industrial by-products, grape pomace, almond hull and pomegranate peel. For pomegranate peel, the addition of EFE increased gas production linearly from the immediately soluble fraction, and from the insoluble fraction, the potential of gas production (significant linear effect), organic matter digestibility and metabolizable energy. The highest doses were the most effective. As the doses increased, the effectiveness increased accordingly. Unlike pomegranate peel, EFE had a quadratic effect on the indices of almond hull, namely a significant response on gas production from the immediately soluble fraction, the insoluble fraction, potential of gas production, organic matter digestibility and metabolizable energy. The lowest dose was the most effective while the highest dose had inhibitory effects for gas indices, organic matter digestibility and metabolizable energy. On the other hand, this supplementation had no effect on the ruminal fermentation of grape pomace. This study indicates that the response to this feed additive was influenced by the dose, the structure of the substrate, and the interaction between dose and the substrate. Exogenous fibrolytic enzymes could enhance the use of almond hull and pomegranate peel in ruminant nutrition, and reduce their negative environmental impact.
\end{abstract}

Keywords: almond hull, feed additive, grape pomace, pomegranate peel

\# Corresponding author: mr.khalil.abid@gmail.com

\section{Introduction}

In recent years, the dramatic increases in the prices of roughage and concentrates have necessitated the use of alternative feeds in animal nutrition, such as agro-industrial by-products. In addition, the use of agro-industrial by-products in animal nutrition reduces the negative environmental impact of the food industry (Elferink et al., 2008). However, because of their poor quality, many agro-industrial by-products, such as almond hull, grape pomace and pomegranate peel, are rarely used in ruminant nutrition (Shabtay et al., 2008; Basalan et al., 2011; Jafari et al., 2011; Delavar et al., 2014). Nevertheless, in recent years, the use of exogenous fibrolytic enzymes (EFEs) as feed additives for ruminants to increase the nutritive values of poorquality roughage has been the object of several studies. These feed additives reportedly increased digestibility (Salem et al., 2013, Santana et al., 2018), milk production (Mohamed et al., 2013) and average daily gain of ruminants (Salem et al., 2013). In contrast, other studies reported that exogenous fibrolytic enzymes had minor effects (Peters et al., 2015). However, no studies have evaluated the effect of this additive on grape pomace, almond hull and pomegranate peel. Therefore, the aim of this study was to evaluate the effects of commercial EFES on these agro-industrial by-products.

\section{Materials and Methods}

Samples of grape (Vitis vinifera) pomace, almond (Prunus amygdalus) hulls and pomegranate (Punica granatum) peels were collected from various regions in Tunisia. Samples were pre-dried at $55^{\circ} \mathrm{C}$ in an oven 
to constant weight, then ground through a $1 \mathrm{~mm}$ screen. Dry matter (DM), organic matter (OM), crude protein $(\mathrm{CP})$, crude fibre $(\mathrm{CF})$, ether extracts (EE), calcium $(\mathrm{Ca})$ and phosphorus were determined according to the methods described by AOAC (1990). Neutral detergent fibre (NDF), acid detergent fibre (ADF) and acid detergent lignin (ADL) were assessed according to the method described by Van Soest et al. (1991), using a fibre analyser (ANKOM ${ }^{220}$, ANKOM Technology, Macedon, NY). Condensed tannin (CT) contents were determined according to the method described by Makkar (2000). The chemical analyses were conducted in triplicate.

The nitrogen-free extract (NFE) was obtained from the equation:

$\mathrm{NFE}=100-(\mathrm{NDF}+\mathrm{CP}+\mathrm{EE}+\mathrm{ash})(\mathrm{NRC}, 2001)$

Hemicellulose and cellulose were calculated, using the difference between NDF and ADF, and between ADF and ADL, respectively (Van Soest et al., 1991).

The EFEs that were used in this study were a liquid mixture of cellulase plus and xylanase plus $(1: 1 / v: v)$ (Dyadic International Inc., Jupiter Florida, USA), which were extracted from Trichoderma longibrachiatum and analysed for their xylanase, endoglucanase and exoglucanase activities in three repetitions, according to the procedures of Wood \& Bhat (1988) and Bailey et al. (1992). These activities were determined at a pH of 6.6 and a temperature of $39^{\circ} \mathrm{C}$. These reflect the normal rumen conditions of the dairy cow. Xylanase activity was tested using $(1 \%$, w/v) oat spelt xylan (catalogueno.X-0627, Sigma Chemical Co., Saint-Louis, MO, USA) as a substrate. Endoglucanase activity was tested using $1 \%(\mathrm{v} / \mathrm{v})$ medium viscosity carboxymethylcellulose sodium salt (catalogue no.C-4888, Sigma Chemical Co., SaintLouis MO, USA) as a substrate. Exoglucanase activity was examined using cellulose (catalogue no. S-3504, Sigma Chemical Co., St. Louis, MO, USA) as substrate.

The three by-products were sprayed with an EFE at 0 (control), 1 (low), 2 (medium) and $4 \mu \mathrm{L} \mathrm{g/DM}$. These treatments were carried out 12 hours before the beginning of incubation.

The test of the ability of EFE to solubilize DM during the pre-interaction period with industrial by-products prior to incubation with rumen fluid was carried out according to the procedure of Elwakeel et al. (2007). Samples of $1 \mathrm{~g} \mathrm{DM}$ of each substrate, supplemented with the EFE of the appropriate dose, were weighed into glass flasks. Then $100 \mathrm{~mL}$ of distilled water was added. This mixture was stored for 12 hours at ambient temperature. After incubation, residues were recovered by filtration with Whatman 541 filter paper (Whatman Scientific Ltd, Maidstone, Kent, England). DM losses were determined according to the methods described by AOAC (1990).

The in vitro gas production technique (Menke \& Steingass, 1988) was used to study the effect of EFE supplementation on the gas production kinetics of by-product feedstuffs. Samples of $200 \mathrm{mg}$ DM of each ground substrate were mixed with the appropriate enzyme products and doses, then put into $120 \mathrm{~mL}$ serum bottles. Each sample was incubated in triplicate with three runs for each treatment. Two non-lactating, fistulated Holstein cows were used as donors of rumen inoculum. These animals were fed twice daily with $8 \mathrm{~kg} /$ day of grass and $2 \mathrm{~kg} /$ day of a commercial concentrate. Rumen fluid from each animal was collected before the morning feeding via an electric pump. Rumen contents were mixed and filtered through two layers of cheesecloth under a continuous flow of $\mathrm{CO}_{2}$ and were kept at $39^{\circ} \mathrm{C}$ in a water bath. The rumen inoculum was diluted $(1: 2 \mathrm{v} / \mathrm{v})$ with buffer solution (Menke \& Steingass, 1988). Thirty millilitres of the incubation inoculum were added to each serum bottle, which was closed with rubber stoppers, and placed at $39^{\circ} \mathrm{C}$ in a shaking water bath for 96 hours. Three blank samples, that is, serum bottles without substrate, were also used to correct for gas production. Gas pressure was measured at 2, 4, 6, 8, 12, 24, 48, 72 and 96 hours after the start of incubation, using a pressure transducer (model PX4200-0100GI, Omega Engineering Inc., Laval, QC Canada) connected to a visual display transducer (Data Tracker 200, DataTrack Process Instruments Ltd, Christchurch). After each measurement, the gas was released. The net gas pressure for each treatment was calculated by subtracting the gas production from the blank bottles.

Kinetic gas production indices were estimated by using the non-linear model (Proc NLN) procedures of SAS (2001) to fit the data to the exponential model of Ørskov \& McDonald (1979):

$$
\mathrm{GP}_{(\mathrm{t})}=\mathrm{A}+\mathrm{B}\left(1-\mathrm{e}^{-\mathrm{Ct}}\right)
$$

where: GP is the cumulative volume of gas produced $(\mathrm{mL} / \mathrm{g} \mathrm{DM})$;

$t$ is the incubation time $(h)$;

A is the gas production from immediately soluble fraction $(\mathrm{mL} / \mathrm{g} \mathrm{DM})$;

$B$ is the gas production from immediately insoluble fraction $(\mathrm{mL} / \mathrm{g} \mathrm{DM})$;

$A+B$ is the potential of gas production $(\mathrm{mL} / \mathrm{g} \mathrm{DM})$;

$C$ is the rate of gas production for the insoluble fraction $(\mathrm{mL} / \mathrm{h})$. 
The ME values and organic matter degradability (OMD) contents were estimated:

$$
\begin{aligned}
& \mathrm{ME}=2.2+0.136 \times \mathrm{GP}+0.0057 \times \mathrm{CP}(\text { Menke \& Steingass, } 1988) \\
& \mathrm{OMD}=14.88+0.889 \times \mathrm{GP}+0.45 \times \mathrm{CP}+0.0651 \times \text { Ash }(\text { Menke \& Steingass, 1988): }
\end{aligned}
$$

where: $\mathrm{ME}$ is metabolizable energy in $\mathrm{MJ} / \mathrm{kg} \mathrm{DM}$;

OMD is organic matter degradability in \%;

$\mathrm{CP}$ is crude protein in \% DM, ash in \% DM;

GP is the net gas production $(\mathrm{mL})$ from $200 \mathrm{mg}$ after 24 hours of incubation.

A completely randomized design with $4 \times 3$ factorial arrangement was used to assess the effect of the four doses of EFEs and of the three agro-industrial by-products. Mean values of each individual sample from each run in each treatment were used as the experimental unit. Data from the experiment were analysed using the general linear model (Proc GLM) procedure of SAS (2001), with the following model:

$$
Y_{i j k}=\mu+D_{i}+S_{i}+(S \times D)_{i j}+e_{i j k}
$$

where: $Y_{i j k}$ is the dependent variable;

$\mu$ is the overall mean;

$D_{i}$ is the effect of the ith enzyme dose ( $I=$ control, low, medium and high);

$S_{i}$ is the effect of the $j^{\text {th }}$ substrate ( $j=$ grape pomace, almond hull and pomegranate peel);

$(\mathrm{S} \times \mathrm{D})_{\mathrm{ij}}$ is the effect of the interaction between the enzyme dose and substrate;

$\mathrm{e}_{\mathrm{ijk}}$ is the random residual error.

Orthogonal polynomial contrasts were used to examine the linear and quadratic effects of enzymatic preparation doses for each agro-industrial by-product. PROC IML of SAS (2001) was used to generate the orthogonal coefficients of unequally spaced treatment doses. Duncan's multiple range tests were used to test the significance of data means (Duncan, 1955). A difference at $P<0.05$ was considered significant.

\section{Results and Discussions}

Table 1 Chemical composition of grape pomace, almond hull and pomegranate peel (\% dry matter)

\begin{tabular}{lccc}
\hline Constituent (\%) & Grape pomace & Almond hull & Pomegranate peel \\
\hline Dry matter * & 52.2 & 31 & 31.3 \\
Organic matter & 92.2 & 91.6 & 94.3 \\
Crude protein & 14.1 & 3.2 & 2.6 \\
Ether extracts & 9.5 & 1.0 & 2.2 \\
Crude fibre & 27.5 & 13 & 13.5 \\
Neutral detergent fibre & 43.4 & 21.9 & 16.8 \\
Acid detergent fibre & 36 & 19.8 & 16 \\
Acid detergent lignin & 26.8 & 7.8 & 4.6 \\
Hemicellulose & 8.4 & 2.1 & 0.8 \\
Cellulose & 12.6 & 12 & 11.4 \\
Ash & 7.8 & 8.4 & 5.7 \\
Phosphorus & 0.3 & 0.1 & 0.1 \\
Calcium & 0.6 & 0.2 & 0.3 \\
Condensed tannin & 0.8 & 3.8 & 1.5 \\
Nitrogen-free extract & 25.2 & 65.5 & 72.7 \\
\hline
\end{tabular}

\footnotetext{
*\% fresh mass
} 
The chemical compositions of the by-product feedstuffs that were used in this study (Table 1) were consistent with those found by Basalan et al. (2011) for grape pomace, by Jafari et al. (2011) for almond hull, and by Shabtay et al. (2008) for pomegranate peel. The CP levels of almond hull and pomegranate peel were very low, below the level required (7\% - 8\% DM) for optimum rumen function (Van Soest, 1994). The lignin fraction of grape pomace was very high. In fact, the latter decreased the attachment of ruminal microbes to feeds (Paya et al., 2007). The condensed tannin levels of almond hull were very high, which can partially inhibit the activity of rumen flora (Williams \& Coleman, 1992).

The EFE used in this study contained 2267 units of xylanases $/ \mathrm{mL}, 1161$ units of endoglucanase $/ \mathrm{mL}$ and 113 units of exoglucanase $/ \mathrm{mL}$.

The effects of EFE in DM disappearance after 12 hours of pre-incubation are shown in Figure 1. The gas kinetics parameters and rumen fermentation profile are shown in Table 2.

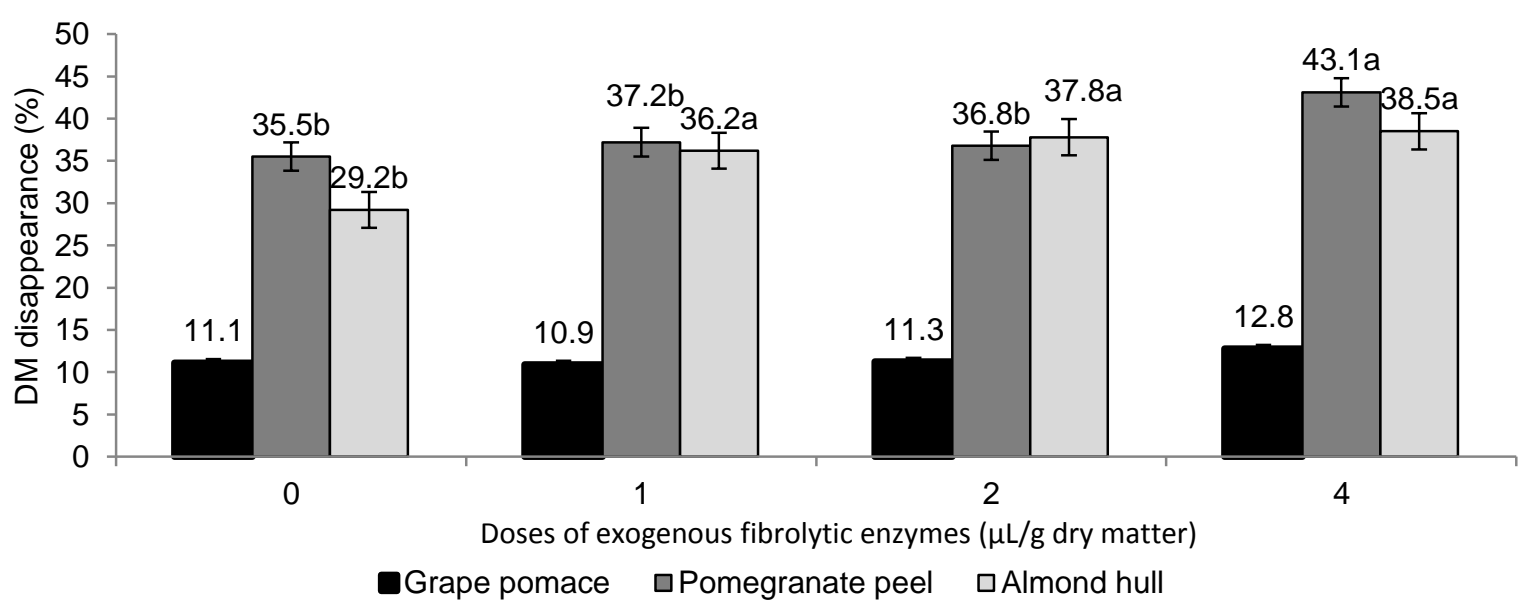

Figure1 Effect of exogenous fibrolytic enzymes on the dry matter disappearance after $12 \mathrm{~h}$ of pre-incubation $a, b$ Different letters following mean doses for each agro-industrial by-product indicate that they are significantly different $(P<0.05)$

The addition of EFE improved gas production from the immediately soluble fraction of pomegranate peel at the highest dose $(P<0.05$, linear effect), and almond hull at a low dose $(P<0.05$, quadratic effect). This effect may be because of partial solubilisation of the DM during pre-incubation (Figure 1). The increase in gas production from the immediately soluble fraction may be a way of overcoming the problem of low intakes of these by-products (Wang et al. 2013). Likewise, Wang et al. (2004) reported that the addition of a fibrolytic enzyme to wheat straw increased the soluble fraction. The supplementation of this additive also improved the gas production from the insoluble fraction of pomegranate peel at the highest dose $(P<0.05$, linear effect), and almond hull at a low dose $(P<0.05$, quadratic effect). This effect may be because of eliminating structural barriers during the pre-incubation period, which increased the attachment of ruminal micro-organisms to undigested feed particles and improved the number of ruminal cellulolytic bacteria (Nsereko et al., 2000; Wang et al., 2001; Giraldo et al., 2008). Moreover, this supplementation increased the potential of gas production, OMD and ME of pomegranate peel at the highest dose $(P<0.05$, linear effect), and almond hull at a low dose $(P<0.05$, quadratic effect). Similar results were found by Togtokhbayar et al. (2015) for wheat straw. However, in the present study the very high dose of EFE had inhibitory effects $(P<0.05$, quadratic effect) for almond hull. The non-linear effects of EFE doses have also been proven in vivo (Kung et al., 2000). Morgavi et al. (2004) hypothesized that the excessive doses of enzyme block the adhesion sites for the bacteria, which decreases microbial adhesion to the substrates. Nsereko et al. (2000) hypothesized that the free hydrolysed sugar that remains bound to the fibre after pre-treatment blocks the sites of action of the enzyme. Treacher \& Hunt (1996) hypothesized that the excessive doses of enzymes can release anti-nutritional factors from the substrate, such as condensed tannin. Unlike with almond hull or pomegranate peel, the addition of EFE to grape pomace did not affect DM solubilize and ruminal fermentation. This result may be because of the high lignin contents of grape pomace, which protect cellulose and hemicelluloses from hydrolytic enzymes (Hatfield et al., 1999). These results showed that the response to EFE addition was influenced by the by-products' substrate. The same result was found by Elghandour et al. (2016) and Santana et al. (2018). 
Table 2 Effect of exogenous fibrolytic enzymes on the gas kinetics indices and rumen fermentation profile of grape pomace, almond hull and pomegranate peel

\begin{tabular}{|c|c|c|c|c|c|c|c|}
\hline \multirow{2}{*}{ Substrate (S) } & \multirow{2}{*}{ Enzyme dosage (D) ( $\mu \mathrm{L} / \mathrm{g} \mathrm{DM})$} & \multicolumn{4}{|c|}{ Gas kinetic indices } & \multicolumn{2}{|c|}{ Rumen fermentation profile } \\
\hline & & $A$ & B & $A+B$ & C & ME & OMD \\
\hline \multirow{6}{*}{ Almond hull } & 0 & $12.7^{b}$ & $178.4^{b}$ & $191.1^{b}$ & 0.078 & $8.09^{b}$ & $55.2^{b}$ \\
\hline & 1 & $19.7^{\mathrm{a}}$ & $205.1^{\mathrm{a}}$ & $224.8^{a}$ & 0.075 & 9.31 & $63.8^{\mathrm{a}}$ \\
\hline & 2 & $14.9^{b}$ & $176.7^{\mathrm{b}}$ & $191.6^{b}$ & 0.078 & $7.93^{b}$ & $54.2^{b}$ \\
\hline & 4 & $6.2^{\mathrm{C}}$ & $168.2^{c}$ & $174.4^{\mathrm{C}}$ & 0.078 & $7.63^{c}$ & $52.2^{c}$ \\
\hline & Linear & n.s & n.s & n.s & n.s & n.s & n.s \\
\hline & Quadratic & ** & ** & ** & n.s & ** & ** \\
\hline \multirow{6}{*}{ Pomegranate peel } & 0 & $9.4^{\mathrm{b}}$ & $170.1^{\mathrm{b}}$ & $179.5^{\mathrm{b}}$ & 0.158 & $7.20^{b}$ & $49.0^{b}$ \\
\hline & 1 & $10.2^{b}$ & $183.7^{\mathrm{ab}}$ & $193.9^{\mathrm{ab}}$ & 0.157 & $7.60^{\mathrm{ab}}$ & $51.6^{\mathrm{ab}}$ \\
\hline & 2 & $12.1^{\mathrm{b}}$ & $184.3^{\mathrm{ab}}$ & $196.4^{\mathrm{ab}}$ & 0.153 & $7.68^{\mathrm{ab}}$ & $52.1^{\mathrm{ab}}$ \\
\hline & 4 & $18.9^{\mathrm{a}}$ & $195.2^{\mathrm{a}}$ & $214.1^{\mathrm{a}}$ & 0.162 & $8.09^{a}$ & $54.8^{\mathrm{a}}$ \\
\hline & Linear & $* * *$ & * & $* *$ & n.s & * & * \\
\hline & Quadratic & n.s & n.s & n.s & n.s & n.s & n.s \\
\hline \multirow{6}{*}{ Grape pomace } & 0 & 6.2 & 77.7 & 83.9 & 0.150 & 6.27 & 47.8 \\
\hline & 1 & 6.6 & 78.7 & 85.3 & 0.152 & 6.37 & 48.4 \\
\hline & 2 & 5.7 & 84.9 & 90.6 & 0.159 & 6.42 & 48.8 \\
\hline & 4 & 5.7 & 85.4 & 91.1 & 0.170 & 6.46 & 49.1 \\
\hline & Linear & n.s & n.s & n.s & n.s & n.s & n.s \\
\hline & Quadratic & n.s & n.s & n.s & n.s & n.s & n.s \\
\hline \multirow[t]{2}{*}{ SEM } & & 2.7 & 6.1 & 7.1 & 0.17 & 0.52 & 2.0 \\
\hline & $P$-value & & & & & & \\
\hline$S$ & & $\star * \star$ & $\star \star \star *$ & $\star * \star$ & $* \star \star$ & $\star \star \star *$ & $\star \star \star *$ \\
\hline$D$ & & ** & ** & ** & ns & ** & ** \\
\hline$S \times D$ & & * & * & * & ns & * & * \\
\hline \multicolumn{8}{|c|}{$\begin{array}{l}\text { a,b,c: Different superscripts following mean doses in the column for each agro-industrial by-product indicate th } \\
\text { significantly different }(P<0.05) \\
\text { A: gas production from immediately soluble fraction }(\mathrm{mL} / \mathrm{g} \mathrm{DM}) \\
\text { B: gas production from insoluble fraction }(\mathrm{mL} / \mathrm{g} \mathrm{DM}) \\
(\mathrm{A}+\mathrm{B}) \text { : potential of gas production }(\mathrm{mL} / \mathrm{g} \mathrm{DM}) \\
\text { C: rate of gas production for the insoluble fraction }(\mathrm{mL} / \mathrm{h}) \\
\text { ME: metabolizable energy }(\mathrm{MJ} / \mathrm{kg} \mathrm{DM}) ; \mathrm{OMD} \text { : organic matter degradability (\%); SEM: standard error of mean } \\
\text { ns: } P>0.05 ;{ }^{*} P<0.05 ;{ }^{\star \star} P<0.01 ;{ }^{* \star \star} P<0.00\end{array}$} \\
\hline
\end{tabular}

\section{Conclusion}

The effectiveness of EFE was influenced by the chemical composition of the by-products, the dose of the EFE, and the interaction between the dose and the substrate. This feed additive in particular increased the ruminal fermentation of almond hull at the lowest dose and pomegranate peel at the highest dose. It could enhance the use of low quality agro-industrial by-products such as almond hull and pomegranate peel in ruminant nutrition.

\section{Authors' Contribution}

$\mathrm{KA}, \mathrm{JJ}$, and $\mathrm{HY}$ performed the experiments, $\mathrm{KA}$ and $\mathrm{JJ}$ analysed the data. $\mathrm{KA}$ collected by-products and wrote this paper. MK corrected the paper. YB, AM, JR and MK supervised the research project.

\section{Conflicts of Interest Declaration}

The authors declare there are no conflicts of interest. 


\section{References}

AOAC, 1990. Official Method of Analysis. 15th edition. Association of Official Analytical Chemists, Inc, Washington, USA.

Bailey, M.J., Biely, P. \& Kaisa, P., 1992. Interlaboratory testing of methods for assay of xylanase activity. J. Biotechnol. 23, 257-270.

Basalan, M., Gungor, T., Owens, F.N. \& Yalcinkaya, I., 2011. Nutrient content and in vitro digestibility of Turkish grape pomaces. Anim. Feed Sci. Technol. 169, 194-198.

Delavar, M.H., Tahmasbi, A.M., Danesh-Mesgaran, M. \& Vali-zadeh, R., 2014. In vitro rumen fermentation and gas production: Influence of different by-product feedstuffs. Ann. Res. Rev. Biol. 4, 1121-1128.

Duncan, D.B., 1955. Multiple range and multiple F Tests. Biometrics 11, 1- 42.

Elferink, E.V., Nonhebel, S. \& Moll, H.C., 2008. Feeding livestock food residue and the consequences for the environmental impact of meat. J. Clean. Prod. 16, 1227-1233.

Elghandour, M.M.Y., Kholif, A.E., Hernández, J., Mariezcurrena, M.D., López, S., Camacho, L.M., Márquez, O. \& Salem, A.Z.M., 2016. Influence of the addition of exogenous xylanase with or without pre-incubation on the in vitro ruminal fermentation of three fibrous feeds. Czech. J. Anim. Sci. 61, 262-272.

Elwakeel, E.A., Titgemeyer, E.C., Johnson, B.J., Armendariz, C.K. \& Shirley, J.E., 2007. Fibrolytic enzymes to increase the nutritive value of dairy feedstuffs. J. Dairy Sci. 90, 5226-5236.

Giraldo, L.A., Tejido, M.L., Ranilla, M.J., Ramos, S. \& Carro, M.D., 2008. Influence of direct-fed fibrolytic enzymes on diet digestibility and ruminal activity in sheep fed a grass hay-based diet. J. Anim. Sci. 86, 1617-1623.

Hatfield, R.D., Ralph, J. \& Grabber, J.H., 1999. Cell wall structural foundations: Molecular basis for improving forage digestibilities. Crop. Sci. 39, 27-37.

Jafari, S., Alizadeh, A. \& Imani, A., 2011. Nutritive value of different varieties of almond (Prunus dulcis) hulls. J. Res. Opin. Anim. Vet. Sci. 11, 734-738.

Kung Jr, L., Cohen, M.A., Rode, L.M. \& Treacher, R.J., 2002. The effect of fibrolytic enzymes sprayed onto forages and fed in a total mixed ratio to lactating dairy cows. J. Dairy Sci. 85, 2396-2402.

Makkar, H.P.S., 2000. Quantification of tannins in tree foliage. IAEA. A laboratory manual FAO/IAEA Working Document, Vienna, Austria.

Menke. K.H. \& Steingass. H., 1988. Estimation of the energetic feed value obtained from chemical analysis and in vitro gas production using rumen fluid. Anim. Res. Dev. 28, 7-55.

Mohamed, D.E.A., Borhami, B.E., El-Shazly, K.A. \& Sallam, S.M.A., 2013. Effect of dietary supplement with fibrolytic enzymes on the productive performance of early lactating dairy cows. J. Agr. Sci., Cambridge 5, 146-155.

Morgavi, D.P., Beauchemin, K.A., Nsereko, V.L., Rode, L.M., McAllister, T.A. \& Wang, Y., 2004. Trichoderma enzymes promote Fibrobacter succinogenes $\mathrm{S} 85$ adhesion to, and degradation of, complex substrates but not pure cellulose. J. Sci. Food. Agr. 84, 1083-1090.

NRC, 2001. Nutrient Requirements of Dairy Cattle. 7th edition. National Academies Press, Washington, USA.

Nsereko, V.L., Morgavi, D.P., Rode, L.M., Beauchemin, K.A. \& McAllister T.A., 2000. Effects of fungal enzyme preparations on hydrolysis and subsequent degradation of alfalfa hay fiber by mixed rumen microorganisms in vitro. Anim. Feed. Sci. Technol. 88, 153-170.

Ørskov, E.R. \& McDonald, I., 1979. The estimation of protein degradability in the rumen from incubation measurements weighed according to rate of passage. J. Agric. Sci. 92, 499-503.

Paya, H., Taghizadeh, A., Janmohammadi, H. \& Moghadam, G.A., 2007. Nutrient digestibility and gas production of some tropical feeds used in ruminant rations estimated by the in vivo and in vitro gas production techniques. Amer. J. Anim. Vet. Sci. 2, 108-113.

Peters, A., Meyer, U. \& Danicke, U., 2015. Effect of exogenous fibrolytic enzymes on performance and blood profile in early and mid-lactation Holstein cows. Anim. Nutr. 1, 229-238.

Salem, A.Z.M., Gado, H.M., Colombatto, D. \& Elghandour, M.M.Y., 2013. Effects of exogenous enzymes on nutrient digestibility, ruminal fermentation and growth performance in beef steers. Livest. Sci. 154, 69-73.

Santana, Y.A.G., Vasconcelos, V.R., Alves, A.A., Silva, S.C.D.M.L. \& Garcez, B.S., 2018. Fermentation characteristics in hay from Cynodon and crop stubble treated with exogenous enzymes. Rev. Ciênc. Agron. 49, 167-173.

SAS, 2001. Statistical Analysis Systems. STAT User's guide. Statistics version 9.1. SAS Institute Inc., Cary, NC, USA.

Shabtay, A., Eitam, H., Tadmor, Y., Orlov, A., Meir, A., Weinberg, P., Weinberg, Z.G., Chen, Y., Brosh, A., Izhaki, I. \& Kerem, Z., 2008. Nutritive and antioxidative potential of fresh and stored pomegranate industrial byproduct as a novel beef cattle feed. J. Agr. Food. Chem. 56, 10063-10070.

Togtokhbayar, N., Cerrillo, M.A., Rodriguez, G.B., Elghandour, M.M.Y., Salem, A.Z.M., Urankhaich, C., Jigidpurev, S., Odongo, N.E. \& Kholif, A.E., 2015. Effect of exogenous xylanase on rumen in vitro gas production and degradability of wheat straw. Anim. Sci. J. 86, 765-771.

Treacher, R.J. \& Hunt, C.W., 1996. Recent developments in feed enzymes for ruminant rations. In: Proceedings Pacific Northwest Animal Nutrition Conference, Seattle, Washington, USA. pp. 37-54. January 14-15, 1996.

Van Soest, P.J., 1994. Nutritional Ecology of the Ruminant. 2nd edition. Cornell University Press, Ithaca, NY, USA.

Van Soest, P.J., Robertson, J.B. \& Lewis, B.A., 1991. Methods for dietary fiber, neutral detergent fiber and nonstarch polysaccharide in relation to animal nutrition. J. Dairy. Sci. 74, 35833597.

Wang, M., Sun, X.Z., Tang, S.X., Tan, Z.L. \& Pecheco, D., 2013. Deriving fractional rate of degradation of logisticexponential (LE) model to evaluate early in vitro fermentation. Animal 7, 920-929.

Wang, Y., McAllister, T.A., Rode, L.M., Beauchemin, K.A., Morgavi, D.P., Nsereko, V.L., Iwaasa, A.D. \& Yang, W., 2001. Effects of an exogenous enzyme preparation on microbial protein synthesis, enzyme activity and attachment to feed in the rumen simulation technique (Rusitec). Br. J. Nutr. 85, 325-332. 
Wang, Y., Spratling, B.M., ZoBell, D.R., Wiedmeier, R.D. \& McAllister, T.A., 2004. Effect of alkali pretreatment of wheat straw on the efficacy of exogenous fibrolytic enzymes. J. Anim. Sci. 82, 198-208.

Williams, A. \& Coleman, G., 1992. The Rumen Protozoa. Springer Verlag, New York, USA.

Wood, T.M. \& Bhat, K.M., 1988. Method for measuring cellulose activities. In: Wood, W.A. \& Kellog, S.T. (Eds), Methods in Enzymology. Academic Press, Inc. London, pp. 87-112. 